\title{
Long-term fire activity under the East Asian monsoon responding to spring insolation, vegetation type, global climate, and human impact inferred from charcoal records in Lake Biwa sediments in central Japan
}

\section{Jun Inoue, Chikako Okuyama and Keiji Takemura}

\begin{tabular}{|c|c|}
\hline Citation & Quaternary Science Reviews, 179; 59-68 \\
\hline Issue Date & 2018-01-01 \\
\hline Type & Journal Article \\
\hline Textversion & author \\
\hline Right & $\begin{array}{l}\text { (c) } 2017 \text { Elsevier Ltd. This manuscript version is made available under the CC-BY-NC-ND } \\
\text { 4.0 License. https://creativecommons.org/licenses/by-nc-nd/4.0/ . The article has been } \\
\text { published in final form at https://doi.org/10.1016/j.quascirev.2017.11.007. }\end{array}$ \\
\hline DOI & 10.1016/j.quascirev.2017.11.007 \\
\hline Description & 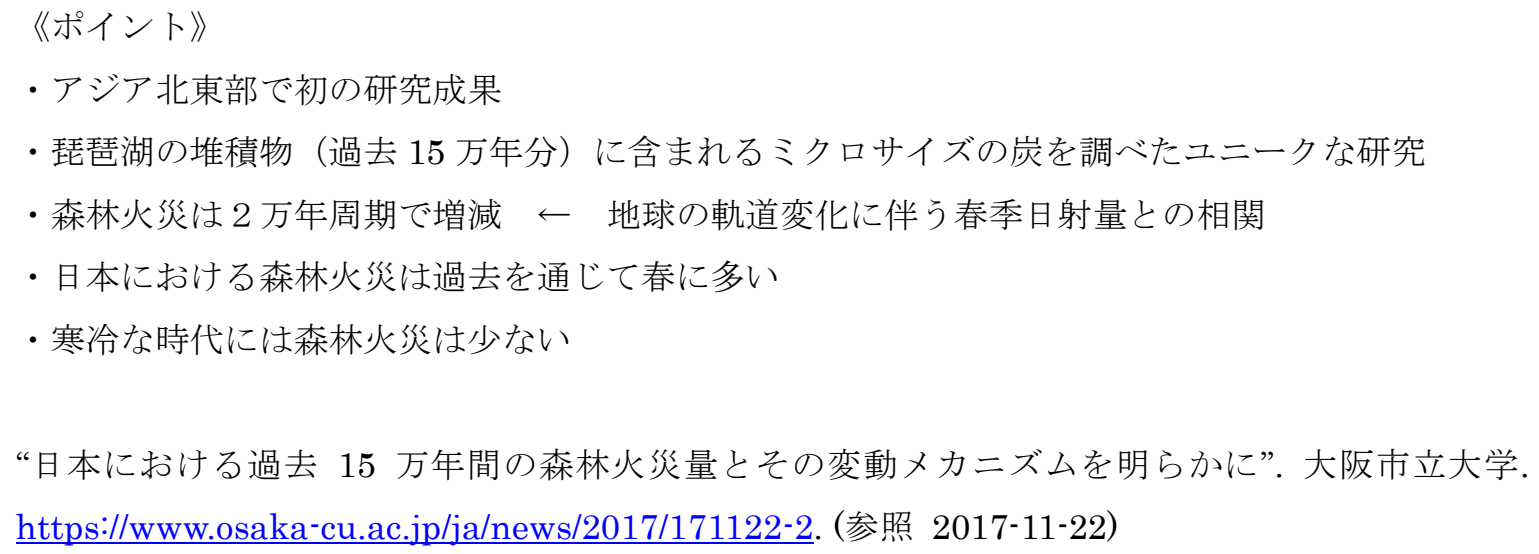 \\
\hline
\end{tabular}

Self-Archiving by Author(s)

Placed on: Osaka City University Repository

INOUE, J., OKUYAMA, C., \& TAKEMURA, K. (2018). Long-term fire activity under the East Asian monsoon responding to spring insolation, vegetation type, global climate, and human impact inferred from charcoal records in Lake Biwa sediments in central Japan. Quaternary Science Reviews. 179, 59-68. doi:10.1016/j.quascirev.2017.11.007 


\title{
Long-term fire activity under the East Asian monsoon responding to spring insolation, vegetation type, global climate, and human impact inferred from charcoal records in Lake Biwa sediments in central Japan
}

\author{
Jun Inoue ${ }^{a}$, Chikako Okuyama ${ }^{a}$, Keiji Takemura \\ a \\ Department of Geosciences, Graduate School of Science, Osaka City University, 3-3-138 Sugimoto, \\ Sumiyoshi-ku, Osaka 558-8585, Japan \\ b \\ Institute for Geothermal Science, Graduate School of Science, Kyoto University, Noguchibaru, Beppu, Ohita \\ 874-0903, Japan \\ *Corresponding author: juni@sci.osaka-cu.ac.jp
}

\begin{abstract}
Records of sedimentary charcoal provide fire histories for assessing the relationship between fires and climate conditions, vegetation, human impact, and other factors. We analyzed charcoal particles in sediments from Lake Biwa in central Japan, dating back to 150,000 years ago. The sediments are well dated, homogenous, and had a constant sedimentation rate, making them ideal for assessing the long-term fire history through charcoal concentration analysis. Low charcoal concentrations in the glacial periods of Marine Isotope Stage (MIS) 2 and 6 indicate that few fires occurred in the periods under the cold climatic conditions. Variations in the microcharcoal concentration between 40,000 and 130,000 years ago, with a periodicity of 21,000-23,000 years, correspond to variations in the spring insolation in central Japan, vegetation type, and global climate, suggesting that the long-term fire activity in central Japan was determined mainly by spring insolation and vegetation type under the influence of global climate change. This finding suggests that insolation changes induced by precession cycles could influence a long-term phenomenon in an area as a direct local effect. Between 16,000 and 3000 years ago, sediments were characterized by an extraordinarily high concentration of large charcoal particles $(>50 \mu \mathrm{m})$ and the predominance of elongated charcoal particles, suggesting that grassland fires (presumably anthropogenic) occurred frequently in the lakeside area. The frequent fire occurrence presumably contributed to the inflow of a large amount of organic materials, resulting in changes in the aquatic environment of Lake Biwa and/or its adjacent area.
\end{abstract}

Keywords: Fire history; Charcoal particle; Spring insolation; Orbital forcing; East Asian monsoon; Local effect

This paper has been published in Quaternary Science Reviews, 179, 59-68 (2018).

DOI: $10.1016 / j . q u a s c i r e v .2017 .11 .007$

C2017. This manuscript version is made available under the CC-BY-NC-ND 4.0 license http://creativecommons.org/licenses/by-nc-nd/4.0/. 


\section{Introduction}

Fire often threatens human life and plays an important role in most ecosystems. Because fire activity has been shown to alter significantly with climate change (e.g., Gillett et al., 2004; Kasischke and Turetsky, 2006; Westerling et al., 2006), many people are concerned about how climate change may alter fire activity in the future. Many previous studies predict future fire activity on Earth using fire-climate models (e.g., Scholze et al., 2006; Pechony and Shindell, 2010; Moritz et al., 2012). Paleorecords in sediments help aid the understanding of interactions between fire and factors such as climate change, vegetation type, and human activity (e.g., Power et al., 2008; Daniau et al., 2012), which could enable prediction of future fire activity.

In regions affected by the East Asian monsoon, such as Japan, present-day wildfires are mostly anthropogenic and are controlled because of the dense population; most fires occur by human carelessness and are extinguished soon (e.g., The Forest Fire Control Association, 2007). The anthropogenic nature of present-day fires prevents us from precisely evaluating the climatic effect on fire activity, so the climatic effect is still unclear in these regions, especially over the long term. Thus the aims of this study are: (1) to show when fires have occurred frequently or infrequently since the glacial period of Marine Isotope Stage (MIS) 6; (2) clarify what factors determined long-term fire regimes under natural conditions, e.g., vegetation type, precipitation, and temperature; and (3) assess how past human activity may have affected fire regimes.

To evaluate the climatic effect on fire activity and interaction between fire and other factors under natural conditions with the East Asian monsoon, we examined charcoal in sediments from Lake Biwa in central Japan (Fig. 1) that were deposited over the last 150,000 years, including periods before clear evidence of the earliest human presence in central Japan (40,000 years ago). Furthermore, comparison between fire activities in the periods before and after human occupation would aid in understanding human effects on fire activity.

Lake Biwa, the largest lake in Japan, is in the central part of Honshu Island (Fig. 1). The north basin is estimated to contain muddy sediments up to approximately $250 \mathrm{~m}$ thick that have been continuously deposited during the last ca. 400,000 years (Meyers et al, 1993; Yoshikawa and Inouchi, 1993). In addition, the sediments are composed of homogeneous mud and the sedimentation rates are almost constant. Therefore, Lake Biwa sediments contain continuous high-quality environmental records from the middle Pleistocene to the present. Studies of various proxies in Lake Biwa sediments show that the records represent changes to the regional environment related to global climate variation. Such records include pollen assemblage (Miyoshi et al., 1999; Hayashi et al., 2010a, b, 2017), diatom assemblage (Kuwae et al., 2002, 2004; Nagayasu et al., 2014), biogenic silica (Xiao et al., 1997a), eolian quartz (Xiao et al., 1997b), fluvial quartz (Xiao et al., 1999), lignin composition (Ishiwatari et al., 2009; Ohira et al., 2014), and branched tetraether lipids (Ajioka et al., 2014). Thus, Lake Biwa sediments are ideal for analysis of charcoal concentration to assess fire history. Variation in charcoal concentration in the sediments likely represents fire activity within the watershed area and its adjacent area.

\section{Material and Methods}

The borehole core BIW08-B (100.3 m long) was collected in 2008 by drilling in Lake Biwa $\left(35^{\circ} 13^{\prime} 41.15^{\prime \prime} \mathrm{N}\right.$ 
and $136^{\circ} 03^{\prime} 21.29^{\prime \prime} \mathrm{E}$ ) at a water depth of $53 \mathrm{~m}$ (Fig. 1 after Takemura et al., 2010). The sediments are mainly composed of dark-gray massive silty clay from 0 to $89 \mathrm{~m}$. This includes those deposited over the last 150,000 years $(0-46 \mathrm{~m})$ used in the present study. We based the age-depth model of the upper $46 \mathrm{~m}$ on the ages of eight volcanic ash layers, K-Ah (7.2 ka), U-Oki (10.2 ka), AT (30.0 ka), SI (46.3 ka), K-Tz (95.2 ka), Aso-ABCD (97.7 ka), Aso-3 (133.0 ka), and Aso-2 (145.8 ka), following Nagayasu et al. (2014; Fig. 2). The dates of K-Ah, U-Oki, AT, and SI were estimated from an age model of the Lake Suigetsu sediments constructed from radiocarbon data and varve counts (Smith et al., 2013). The SI age stems from the correlation between SI (BT-15) in the Lake Biwa sediments and SG06-3668 in the Lake Suigetsu sediments based on the similarity of their glass chemical compositions (Nagahashi et al., 2004; Smith et al., 2013). This age is consistent with the SI age derived using the thermoluminescence method (49 $\pm 10 \mathrm{ka}$; Shitaoka et al., 2013). The dates of K-Tz, Aso-ABCD, Aso-3, and Aso-2 were estimated primarily from the correlation between the marine oxygen isotope ratio (Bassinot et al., 1994) and beds including these volcanic ash layers based on their lithofacies (e.g., marine beds interbedded in terrestrial deposits), palynological data, diatom data, and the age model of the beds, with respect to their radiometric ages (Nagahashi et al., 2004, 2007). Based on the age-depth model of the BIW08-B core, we estimated an average sedimentation rate of $0.3 \mathrm{~m} / \mathrm{ky}$ in this zone. The age-depth model correlates well with the radiometric ages of the tephra and other materials (Fig. 2) and the dated anhysteretic remanent magnetization events in the BIW08-B core shown in Ajioka et al. (2014).

For the charcoal analysis, we took 139 wet subsamples of 1-cm thickness from the upper $46 \mathrm{~m}$ of the core. Subsamples were dried at $50^{\circ} \mathrm{C}$ for 2 days and then weighed. We treated the samples of $\sim 1.5 \mathrm{~g}$ with $10 \%$ $\mathrm{KOH}$ and 46\% HF, and added approximately 208,000 $15 \mu \mathrm{m}$ plastic microspheres (Ogden, 1986) to each sample to facilitate calculation of charcoal concentration. We then filtered the suspension onto a membrane $47 \mathrm{~mm}$ in diameter with a porosity of $5 \mu \mathrm{m}$. A portion of this membrane was mounted onto a slide (Daniau et al., 2013).

Under $200 \times$ and 500x magnification, the charcoal particle was restricted to black, completely opaque, angular particles under transmitted light and plant structure with silky sheen under incident light. We quantified charcoal particles $>20 \mu \mathrm{m}$, because it was difficult to recognize plant structure on particles smaller than this. Charcoal particles were quantified using automated image analysis (NIH Image software ver. 1.62 for Macintosh, developed by the U.S. National Institutes of Health). We measured surface area, length, and width of each charcoal particle and at least 200 plastic microspheres in this study. We divided charcoal particles into three size classes: $20-50 \mu \mathrm{m},>50 \mu \mathrm{m}$, and $>100 \mu \mathrm{m}$. The formation of classes is helpful for distinguishing spatial locations of sources, assuming that larger charcoal particles originate from sources near the deposition site (e.g., Tinner et al., 1998; Whitlock and Larsen, 2001). We estimated the sum of all surfaces of charcoal particles, in each class, in one sample per gram to determine the charcoal concentration. The elongation (length/width ratio) of each 20$50 \mu \mathrm{m}$ charcoal particle was also calculated. We estimated the average elongation of particles in one sample to characterize charcoal morphology and help identify their materials. Finsinger and Tinner (2005) showed that a count of at least 200-300 objects (a sum of charcoal particles and exotic marker grains) would provide a charcoal-concentration (number of charcoal particles) estimate with less than $\pm 5 \%$ error when charcoałmarker 
grain ratios are $0.1-0.91$. In the present study, we counted at least 240 objects (a sum of $20-50 \mu \mathrm{m}$ charcoal particles and exotic marker grains). Charcoałmarker grain ratios in samples ranged from 0.2 to 0.8 , except for $0-4$ $\mathrm{m}$ depth samples presenting an extraordinary high charcoal concentration as shown below. This indicates that charcoal concentration variability is largely meaningful. In addition, concentrations of both abundance and surface area of 20-50 $\mu \mathrm{m}$ charcoal particles are significantly correlated $(\mathrm{r}=0.96)$, similar to Daniau et al. (2013).

\section{Results and Discussion}

\subsection{Charcoal concentrations in Lake Biwa sediment deposited for 150,000 years}

Differences in the variations in the charcoal concentration exist between 20-50 $\mu \mathrm{m}$ and $>50 \mu \mathrm{m}$ or $>100 \mu \mathrm{m}$ particle, even though some similarities exist between them (Fig. 3). The variation patterns in the charcoal concentration between $>50 \mu \mathrm{m}$ and $>100 \mu \mathrm{m}$ are similar to each other. The variations in the charcoal concentrations in the respective sizes of 20-50 $\mu \mathrm{m},>50 \mu \mathrm{m}$, and $>100 \mu \mathrm{m}$ are characterized by an extraordinarily high concentration between $3 \mathrm{ka}$ and $16 \mathrm{ka}$ and high concentrations between $32 \mathrm{ka}$ and $40 \mathrm{ka}$. The 20-50 $\mu \mathrm{m}$ charcoal concentrations are low from $20 \mathrm{ka}$ to $29 \mathrm{ka}$ and from $134 \mathrm{ka}$ to $150 \mathrm{ka}$ and fluctuated between $133 \mathrm{ka}$ and $30 \mathrm{ka}$. Conversely, the $>50 \mu \mathrm{m}$ and $>100 \mu \mathrm{m}$ charcoal concentrations are generally low prior to $39 \mathrm{ka}$ with some random peaks. In particular, very few or no $>100 \mu \mathrm{m}$ charcoal particles were observed prior to $39 \mathrm{ka}$ (generally 0-2 particles) and the random peaks are due to extremely large charcoal particles ( $>200 \mu \mathrm{m})$, whereas between $3 \mathrm{ka}$ and $16 \mathrm{ka}$, the numbers of observed $>100 \mu \mathrm{m}$ charcoal particles are generally $\sim 10$. The difference in the variations in the charcoal concentration in the size differences is likely due to the difference in the spatial locations of their sources. The $>100 \mu \mathrm{m}$ charcoal particles (called macro-charcoal) are not transported far from their source (fire area) before settling, whereas small charcoal particles can be transported great distances (e.g., Tinner et al., 1998; Whitlock and Larsen, 2001). Given this fact, we infer that the $>100 \mu \mathrm{m}$ charcoal particles in the Lake Biwa sediments were primarily from fires in the watershed area, especially from fires in the lakeside area, whereas the 20-50 $\mu \mathrm{m}$ charcoal particles were likely from fires in the watershed and/or its surrounding area. The similarity in the variation patterns of the $>100 \mu \mathrm{m}$ and $>50 \mu \mathrm{m}$ charcoal concentrations indicates that the source of the $>50 \mu \mathrm{m}$ charcoal particles is generally similar to that of the $>100 \mu \mathrm{m}$ particles. Therefore, the variations in the concentrations of the $20-50 \mu \mathrm{m}$ charcoal particles primarily represent fire activity in the regional area and those of the $>50 \mu \mathrm{m}$ and $>100 \mu \mathrm{m}$ particles represent local fire activity, primarily in the lakeside area. Variations in the charcoal concentrations of all size classes are characterized by an extraordinarily high concentration between $3 \mathrm{ka}$ and $16 \mathrm{ka}$ (Fig. 3) and high concentrations between $32 \mathrm{ka}$ and $40 \mathrm{ka}$. This indicates that most 20-50 $\mu \mathrm{m}$ charcoals in these periods were from local fires and not regional ones. Conversely, the 20-50 $\mu \mathrm{m}$ charcoal concentrations in other periods primarily represent regional fire activity.

\subsection{Regional fire activity since the beginning of the last interglacial period}

First, we focus on $20-50 \mu \mathrm{m}$ charcoal concentrations to reconstruct past regional fire activity. We obtained three samples running average of 20-50 $\mu \mathrm{m}$ charcoal concentrations to represent a general regional fire 
activity trend (Fig. 4D). To assess the relationships between regional fire activity and climatic change or vegetation type, we compared charcoal (20-50 $\mu \mathrm{m})$ concentrations with the LR04 marine isotope stack (Fig. 4E; Lisiecki and Raymo, 2005) and the main vegetation type inferred from palynological data of sediment cores from Lake Biwa (Fig. 4F; Hayashi et al., 2010a, b; 2017). As mentioned above, 20-50 $\mu \mathrm{m}$ charcoals are scarce in sediments between 20-29 and 134-150 ka. These periods almost correspond to MIS 2 and 6, respectively. MIS 2 and 6 are characterized by a cold climate and dominance of pinaceous conifer forests in the region (Figs. 4E and F). The general decreasing trend in charcoal concentration from 130 to 60 ka roughly corresponds to the increase in the oxygen isotope ratio from MIS 5e to 4, which indicates an increase in northern hemisphere ice volume and a global cooling trend.

In some periods, the ratio of syringyl to vanillyl phenols ( $\mathrm{S} / \mathrm{V}$ ratio) in the BIW08-B core, which indicates the ratio of broad-leaf trees to conifer trees, correlates with the charcoal concentration (e.g., 56 $\mathrm{ka}, 103 \mathrm{ka}$, and $125 \mathrm{ka}$, which are represented as blue lines, and $46 \mathrm{ka}, 67 \mathrm{ka}$, and $92 \mathrm{ka}$, which are represented as red lines in Figs. 4B and 4D). Hayashi et al. (2017) demonstrated that, in Japan, changes in the summer insolation should have negatively influenced the summer precipitation, as suggested by the dominance of Cryptomeria during periods of weak summer insolation with strong winter insolation. Ohira et al. (2014) also indicated that the ratio of conifer forest (primarily composed of Cryptomeria between MIS 5 and MIS 3, except for MIS 4) to broad-leaf forest was negatively correlated with the summer insolation (Figs. 4B and 4C). These facts imply that the fire activity was low during periods with low summer precipitation and vice versa between MIS 5 and MIS 3. This correlation suggests that the fire activity was not directly controlled by the summer precipitation (or the dryness in the summer) since MIS 6 in this region. This is likely due to the small amount of variation in the summer precipitation since MIS 6, as estimated by a modern analog technique using palynological data of the Lake Biwa sediments (Nakagawa et al., 2008). An increase in the fire activity in the periods under the dominance of Cryptomeria is presumably due to the fact that Cryptomeria is more fire-prone than other vegetation types such as broad-leaf forest, as explained below.

We applied spectrum analysis to the values of $20-50 \mu \mathrm{m}$ charcoal concentrations between 40 and $130 \mathrm{ka}$ (Fig. 3) to assess the causes of the oscillation of the charcoal concentrations in this period. The reason we excluded the concentration data after $40 \mathrm{ka}$ for the analysis is that after that age, most of the charcoal particles are likely from local, not regional, fires, indicated by accompanying high $>50 \mu \mathrm{m}$ and $>100 \mu \mathrm{m}$ charcoal concentrations. In addition, these charcoals are possibly related to anthropogenic fires, because reliable evidence of the earliest human remains in central Japan dates back to $40 \mathrm{ka}$ (e.g., Kaifu et al., 2015). Figure 5 shows that charcoal concentrations have a periodicity of 21,000-23,000 years, which corresponds to the precession cycle. This fact indicates that fire activity was influenced by insolation of a certain season.

To assess the season in which insolation influenced the fire activity, we applied multiple regression analysis, assuming that global climatic changes and insolation of a certain season influenced fire activity. For the multiple regression analysis, we used the LR04 marine isotope stack (Fig. 4E) and insolation at $35^{\circ} \mathrm{N}$ (latitude of Lake Biwa) every $\sim 10$ days, i.e., January 1, 11, 21, February 1, 11,.., as independent 
variables to represent $20-50 \mu \mathrm{m}$ charcoal concentrations between 40 and $140 \mathrm{ka}$, and calculated adjusted $\mathrm{R}^{2}$ values. Data of three samples running average of charcoal (20-50 $\mu \mathrm{m})$ concentrations were used for the analysis. Ages of the data were rounded to the nearest 1000 years, because the marine isotope stack and insolation were given at 1000 years intervals. The data of charcoal concentrations used for the analysis were approximately normally-distributed, as shown in Figure 6A. Figure 6B shows adjusted $\mathrm{R}^{2}$ values for each date. The coefficient of insolation at each date between January and May for the equation developed from the multiple regression analysis is positive, suggesting that the insolation at each date in Fig. 6B positively correlates with the charcoal concentrations. The highest adjusted $R^{2}$ value is on March $1\left(R^{2}=0.35\right.$; Fig. $\left.6 B\right)$, corresponding to early spring in Japan. The result of the analysis using the LR04 marine isotope stack and the March 1 insolation is shown in supplementary Table 1. Residuals show a random pattern, indicating a good fit for a liner model (Fig. 6C). Standardized residuals were approximately normally-distributed (Fig. 6D). In addition, the correlation coefficients (single regression analysis) of the charcoal concentrations versus the LR04 marine isotope stack $\left(\mathrm{R}^{2}\right.$ $=0.20)$ and the charcoal concentrations versus the March 1 insolation $\left(R^{2}=0.04\right)$ were very low. These results imply that the coupling of the LR04 marine isotope stack and the spring insolation can largely explain the observed variation in the charcoal concentrations, i.e., both the global climate change and the spring insolation presumably influenced the fire activity in central Japan. We calculated the regression equation for charcoal concentrations using the LR04 marine isotope stack and the March 1 insolation (Fig. 6E). The variation trend in computed concentrations is similar to that in the original concentration, though there are some differences between them. Furthermore, variation in spring insolation correlates with variation in the charcoal concentration (Figs. 4C and D). These findings suggest that spring insolation significantly influenced fire activity, implying that fires tended to occur in the spring in the past. This is consistent with the fact that most fires at present in Japan, regardless of the vegetation type (Fig. 1), occur in the spring and tend to spread, resulting in larger fires (Fig. 7). In addition, trend of fire occurrence in Shiga Prefecture (almost corresponding to Lake Biwa's watershed area) is similar to that in Japan as a whole (Fig. 7). One of the main reasons for this trend is an increase in flammability of the fuel due to low precipitation and high temperature during this season, which makes fuel available to burn and contributes to the start and spread of fires. In contrast, the summer monsoon contributes to wind from the Pacific Ocean, resulting in high precipitation in the summer, and the winter monsoon contributes to wind from the Eurasian continent that passes over the Sea of Japan, resulting in cold temperatures and snowfall. Thus, in other seasons, high precipitation or low temperatures and snow cover prevent fuel from drying, thus lowering the occurrence of fires.

Past regional fire activity inferred from charcoal concentration response to climate change and spring insolation may be explained by the following mechanisms. Low charcoal concentrations in MIS 2 and 6 are probably due to cold conditions, especially in spring, preventing fuel from drying and snow from melting. Based on modern observations in Japan, the evaporation rate from litter on the forest floor is significantly dependent on solar radiation, and the evaporation rate determines litter (fuel) moisture content (Tamai and Hattori, 1994; Tamai, 2001; Tamai and Goto, 2006). Because fuel moisture content is critical for fire ignition, 
solar radiation would significantly affect the potential for fire (e.g., Tamai, 2001; Scott et al., 2014). Furthermore, changes in spring insolation increase spring temperatures, and these higher temperatures contribute to earlier snow melt and drier fuel. Thus, spring insolation has largely affected fire activity in central Japan over the long term, especially for fire-ignition potential.

Some differences between trends of variation in 20-50 $\mu \mathrm{m}$ charcoal concentrations and spring insolation (Figs. 4C and D), and the difference in original and computed charcoal concentration (Fig. 6E) are presumably due to the fact that the fire regime is also dependent on vegetation type. As mentioned above, between 40 and $130 \mathrm{ka}$, variation in charcoal concentrations also roughly corresponds to fluctuation of vegetation composition represented by the S/V ratio in the BIW08-B core (Fig. 4B; Ohira et al., 2014). The S/V ratio represents an index of deciduous broad-leaved trees, mainly deciduous oaks, versus temperate conifers of Cryptomeria. Based on the relationship between modern forest type and fire incidence in Japan, deciduous broad-leaved trees are much more fireproof than Cryptomeria, and the fire incidence in broad-leaved forests is less than one-fourth of that in Cryptomeria forests in modern times (Iizumi et al., 1991). That would explain the correlation between charcoal concentration and $\mathrm{S} / \mathrm{V}$ ratio during some periods. In general, fires start on the surface, where litter, duff, and herbaceous plants and shrubs occur (surface fire). The fire may spread up tree trunks into the crowns of trees (crown fire) (e.g., Scott et al., 2014). This implies that the condition of litter on the forest floor affected fire-ignition potential. Conversely, the vegetation types (fireproof or fire-prone forests) tend to affect the fire-spreading potential. Therefore, the predominance of fireproof forests of deciduous broad-leaved trees (high $\mathrm{S} / \mathrm{V}$ ratio) is associated with fewer opportunities for fire spreading, whereas the predominance of fire-prone forests of Cryptomeria (low S/V ratio) allow for fire spreading.

As mentioned above, vegetation types corresponding to changes in the summer insolation influenced the fire activity and this influence tends to make the charcoal-concentration variation match the insolation at an earlier date. Therefore, even though the charcoal-concentration variation best fits the early-spring insolation (March 1), we assume that it was actually the middle-spring insolation (likely April insolation) that significantly influenced the fire activity as a direct local effect in this region. We conclude that between 40 and $130 \mathrm{ka}$, long-term fire activity under natural conditions in central Japan was determined by a combination of spring insolation and vegetation type under the influence of the global average temperature.

\subsection{Frequent fires in the lakeside area since the terminal Pleistocene}

Variations in $>50 \mu \mathrm{m}$ charcoal particle concentrations are characterized by an extraordinarily high concentration between 16 and $3 \mathrm{ka}$ (Fig. 3 and Fig. 8A). The high charcoal concentrations or fluxes in this period were found in other cores from Lake Biwa (Inoue et al., 2001; Hayashi et al., 2010a) and in other lake and terrestrial sediments near Lake Biwa (Inoue and Yoshikawa, 2005; Inoue et al., 2005), suggesting that fire occurred frequently in the lakeside area. In addition, elongated charcoal particles were the most predominant during this period (Fig. 8B). Experimental analysis conducted on burned grasses and wood from Japan and North America showed that 
charcoal from grasses generally has a greater elongation ratio than charcoal derived from wood (Umbanhowar and McGrath, 1998; Ogura, 1999). We thus infer that grassland fires occurred frequently in the lakeside area during this period. This period was also associated with high concentrations of total organic carbon (TOC) and terrestrial organic carbon (TROC), and a high ratio of cinnamyl to vanillyl phenols (C/V ratio) in the BIW08-B core (Fig. 8C, D, and E; Ohira et al., 2014). The C/V ratio indicates the contribution of non-woody tissues and herbaceous plants, thus, a high $\mathrm{C} / \mathrm{V}$ ratio and high TROC suggest a large amount of organic materials from terrestrial herbaceous plants flew into Lake Biwa during this period (Ohira et al., 2014). Furthermore, palynological records in swamp sediments near Lake Biwa show that grasslands developed in the lakeside area, with fire increasing during this period (Hayashi et al., 2012), supporting our assumption. However, palynological data of the Lake Biwa sediments (Hayashi et al., 2010a, 2017) show that the percentage of herbaceous pollens had been largely stable between 40 and $10 \mathrm{ka}$ (e.g., Gramineae at 10\%-20\%), even though herbaceous pollen slightly increased around $15 \mathrm{ka}$. This is likely due to the difference in the spatial locations of sources between the pollen and the large charcoals or plant materials contributing to changes in the C/V ratio and TROC; most pollen in the Lake Biwa sediments are presumably supplied from regional vegetation within a radius of $150 \mathrm{~km}$ (Hayashi et al., 2017). This is consistent with our assumption that grassland fires occurred frequently in the lakeside area and that herbaceous charcoals flew into the lake.

Although frequent fires were partially due to changing climate between late MIS 2 and early MIS 1, we infer that those fires were mostly anthropogenic. This is because an extraordinarily high charcoal concentration was found only during this period and not during the warmer period of early MIS 5e. Furthermore, spring insolation, which has a positive effect on fire activity under natural conditions as previously shown, was low between 16 and $3 \mathrm{ka}$ (Fig. 4C). Archeological evidence also supports this assumption. The period between 16 and $3 \mathrm{ka}$ almost corresponds to the Jomon era, or the Neolithic era in Japan, which is characterized mainly by hunter-gatherer societies. In Shiga Prefecture, most human remains and ruins from the Jomon era have been discovered in the lakeside area of Lake Biwa. The earliest human remains date back to 15 ka (Hatanaka et al., 2010). Therefore, the coincidence of increasing TOC and charcoal in Lake Biwa sediments suggests that during this period, anthropogenic fires possibly contributed to the inflow of organic carbon. We note that both the increase in charcoal elongation and $\mathrm{C} / \mathrm{V}$ preceded the increase in $>50 \mu \mathrm{m}$ charcoal concentration, TOC, and TROC. This implies that charcoal particles and organic carbon were produced by herbaceous plants without a change of their inflow rate. This finding is presumably because ancient people selectively burned a limited area of the original grassland in the lakeside area. In addition, the fire occurrence in the terminal Pleistocene possibly contributed to the substantial changes in the aquatic environment of the lake and its adjacent area. This is suggested by the fact that Gomphonema is exceptionally dominant in benthic diatoms only around $15 \mathrm{ka}$ in the last $280 \mathrm{ka}$ (Nagayasu et al., 2014), which is coincident with high $>50 \mu \mathrm{m}$ charcoal and TOC concentrations. Due to the fire occurrence in the lakeside, terrestrial herbaceous materials flew into the lake or the adjacent river and small bogs connected to the lake, probably resulting in eutrophication and other aquatic environment changes. We assume the decrease in charcoal after $2.5 \mathrm{ka}$, corresponding to the Yayoi era, was due to a lifestyle 
characterized by rice cultivation on a paddy, because many Yayoi-era archeological sites have been discovered around Lake Biwa (Hatanaka et al., 2010).

\section{Conclusion}

Between 130 and $40 \mathrm{ka}$, fire activity was dependent on spring insolation, vegetation type, and global climate change in this region. During these periods, higher spring insolation, fire-prone vegetation, and higher temperatures resulted in higher fire activity, whereas lower spring insolation, fireproof vegetation, and lower temperatures resulted in lower fire activity. This indicates that fires occurred mostly in the spring, which is similar to what happens today. Few fires occurred during the glacial periods of MIS 2 and 6 . Between 16 and 3 $\mathrm{ka}$, grassland fires were concentrated in the lakeside area of Lake Biwa, as suggested by extremely high concentrations of large charcoal particles and the predominance of elongated charcoal particles. This is consistent with charcoal concentration or flux and other proxies (e.g., palynological data) recorded in sediments from Lake Biwa and adjacent areas. We assume that the frequent fires were probably anthropogenic, which is supported by archeological evidence around the lake. Correlations between large charcoal (>50 $\mu \mathrm{m})$ concentrations and TROC contents or benthic diatom assemblages in Lake Biwa sediments indicate that the increase of sedimentary organic carbon and the change of the aquatic environment were presumably related to the fires.

\section{Acknowledgments}

We are grateful to Muneki Mitamura (Osaka City University) for fruitful discussions during the course of this work; Shusaku Yoshikawa (Osaka City University) for providing the idea of working on charcoal analysis of Lake Biwa sediments; Masanobu Yamamoto (Hokkaido University) for providing the lignin data; Ryoma Hayashi (Lake Biwa Museum) for providing the palynological data; Kohtaro Hirose (Waseda University) for discussing the diatom data with us; and Morteza Djamali and another reviewer for fruitful reviews. We would like to thank all the members of the BIW08 drilling project. This work was supported in part by Grants-in-Aid for Scientific Research from the Ministry of Education, Culture, Sports, Science and Technology of Japan (No. 22710015 to J. Inoue, and No. 19204050 to K. Takemura).

\section{Reference}

Ajioka, T., Yamamoto, M., Takemura, K., Hayashida, A., Kitagawa, H., 2014. Water pH and temperature in Lake Biwa from MBT'/CBT indices during the last 280,000 years. Clim Past 10, $1843-1855$.

Bassinot, F.C., Labeyrie, L.D., Vincent, E., Quidelleur, X., Shackleton, N.J., Lancelot, Y., 1994. The Astronomical Theory of Climate and the Age of the Brunhes-Matuyama Magnetic Reversal. Earth and Planetary Science Letters 126, 91-108.

Berger, A.L., 1978. Long-Term Variations of Daily Insolation and Quaternary Climatic Changes. J Atmos Sci 35, 2362-2367.

Daniau, A.L., Bartlein, P.J., Harrison, S.P., Prentice, I.C., Brewer, S., Friedlingstein, P., Harrison-Prentice, T.I., Inoue, J., Izumi, K., Marlon, J.R., Mooney, S., Power, M.J., Stevenson, J., Tinner, W., Andric, M., Atanassova, J., Behling, H., Black, M., Blarquez, O., Brown, K.J., Carcaillet, C., Colhoun, E.A., Colombaroli, D., Davis, B.A.S., D'Costa, D., Dodson, J., Dupont, L., Eshetu, Z., Gavin, D.G., Genries, A., Haberle, S., Hallett, D.J., Hope, G., Horn, S.P., Kassa, T.G., Katamura, F., Kennedy, L.M., Kershaw, P., Krivonogov, S., Long, C., Magri, D., Marinova, E., McKenzie, G.M., Moreno, P.I., Moss, P., Neumann, F.H., Norstrom, E., Paitre, C., Rius, D., Roberts, N., Robinson, 
G.S., Sasaki, N., Scott, L., Takahara, H., Terwilliger, V., Thevenon, F., Turner, R., Valsecchi, V.G., Vanniere, B., Walsh, M., Williams, N., Zhang, Y., 2012. Predictability of biomass burning in response to climate changes. Global Biogeochem Cy 26, GB4007.

Daniau, A.L., Goni, M.F.S., Martinez, P., Urrego, D.H., Bout-Roumazeilles, V., Desprat, S., Marlon, J.R., 2013. Orbital-scale climate forcing of grassland burning in southern Africa. P Natl Acad Sci USA 110, 5069-5073.

Finsinger, W., Tinner, W., 2005. Minimum count sums for charcoal-concentration estimates in pollen slides: accuracy and potential errors. Holocene 15, 293-297.

Gillett, N.P., Weaver, A.J., Zwiers, F.W., Flannigan, M.D., 2004. Detecting the effect of climate change on Canadian forest fires. Geophys Res Lett 31, L18211.

Hammer, Ø., Harper, D.A.T., Ryan, P.D., 2001. PAST: Paleontological Statistics Software Package for Education and Data Analysis. Palaeontologia Electronica 4, 9pp.

Hatanaka, S., Ido, S., Hayashi, H., Nakai, H., Hujita, T., 2010. History of Shiga Prefecture. Yamakawa Shuppansha, Tokyo.

Hayashi, R., Takahara, H., Hayashida, A., Takemura, K., 2010a. Millennial-scale vegetation changes during the last 40,000 yr based on a pollen record from Lake Biwa, Japan. Quaternary Res 74, 91-99.

Hayashi, R., Takahara, H., Yoshikawa, S., Inouchi, Y., 2010b. Orbital-scale vegetation variability during MIS 6, 5, 4, and 3 based on a pollen record from the Takashima-oki core in Lake Biwa, western Japan. Japanese Journal of Palynology $56,5-12$.

Hayashi, R., Inoue, J., Makino, M., Takahara, H., 2012. Vegetation history during the last 17,000 years around Sonenuma Swamp in the eastern shore area of Lake Biwa, western Japan: With special reference to changes in species composition of Quercus subgenus Lepidobalanus trees based on SEM pollen morphology. Quatern Int 254, 99-106.

Hayashi, R., Takahara, H., Inouchi, Y., Takemura, K., \& Igarashi, Y., 2017. Vegetation and endemic tree response to orbital-scale climate changes in the Japanese archipelago during the last glacial-interglacial cycle based on pollen records from Lake Biwa, western Japan. Review of Palaeobotany and Palynology 241, 85-97.

Igarashi, Y., Oba, T., 2006. Fluctuations in the East Asian monsoon over the last $144 \mathrm{ka}$ in the northwest Pacific based on a high-resolution pollen analysis of IMAGES core MDOI-2421. Quaternary Sci Rev 25, 1447-1459.

Iizumi, S., Kikuchi, T., Miura, O., Shitara, H., Tsuda, S., 1991. Fire ecology. Tokai University Press, Kanagawa.

Inoue, J., Takahara, H., Chijiwa, K., Yoshikawa, S., 2005. Fire history since 17,000 yr BP reconstructed from charcoal particles analysis of the Sonenuma Swamp sediments, Shiga Prefecture, Japan. Japanese Journal of Historical Botany 14, 47-54.

Inoue, J., Takahara, H., Yoshikawa, S., Inouchi, Y., 2001. Reconstruction of fire history during the last 130 ka by analysis of microscopic charcoal in Lake Biwa sediment. The Quaternary Research (Daiyonki-Kenkyu) 40, 97-104.

Inoue, J., Yoshikawa, S., 2005. Research on black plant particles in Ando-soils distributed around Lake Biwa, central Japan, with a new avenue of research on charcoal particles in Ando-soils. The Quaternary Research (Daiyonki-Kenkyu) 44, 289-296.

Ishiwatari, R., Negishi, K., Yoshikawa, H., Yamamoto, S., 2009. Glacial-interglacial productivity and environmental changes in Lake Biwa, Japan: A sediment core study of organic carbon, chlorins and biomarkers. Org Geochem 40, 520-530.

Japanese Fire and Disaster Management Agency, 2002-2012. A white paper on fire and disaster management (2002-2012). Japanese Fire and Disaster Management Agency, Tokyo. Available at Japanese Fire and Disaster Management Agency website (http://www.fdma.go.jp/concern/publication/).

Japanese Fire and Disaster Management Agency, 2005. Report of the meeting for effective measures against wildfires. Japanese Fire and Disaster Management Agency, Tokyo. Available at Institution of Scientific Approaches for Fire \& Disaster website (http://www.bousaihaku.com/bousai_img/houkokusyørinya/rall.pdf).

Kaifu, Y., Izuho, M., Goebel, T., 2015. Modern human dispersal and behavior in Paleolithic Asia, in: Kaifu, Y., Izuho, M., Goebel, T., Sato, H., Ono, A. (Eds.), Emergence and diversity of modern human behavior in Plaeoithic Asia Texas A\&M University Press, College Station, pp. 535-566.

Kasischke, E.S., Turetsky, M.R., 2006. Recent changes in the fire regime across the North American boreal region-Spatial and temporal patterns of burning across Canada and Alaska. Geophys Res Lett 33, L09703.

Kuwae, M., Yoshikawa, S., Inouchi, Y., 2002. A diatom record for the past 400 ka from Lake Biwa in Japan correlates with global paleoclimatic trends. Palaeogeogr Palaeocl 183, 261-274.

Kuwae, M., Yoshikawa, S., Tsugeki, N., Inouchi, Y., 2004. Reconstruction of a climate record for the past 140 kyr based on diatom valve flux data from Lake Biwa, Japan. J Paleolimnol 32, 19-39.

Laskar, J., Robutel, P., Joutel, F., Gastineau, M., Correia, A.C.M., Levrard, B., 2004. A long-term numerical solution for the insolation quantities of the Earth. Astron Astrophys 428, 261-285.

Lisiecki, L.E., Raymo, M.E., 2005. A Pliocene-Pleistocene stack of 57 globally distributed benthic delta O-18 records. Paleoceanography 20, PA1003.

Meyers, P.A., Takemura, K., Horie, S., 1993. Reinterpretation of Late Quaternary sediment chronology of Lake Biwa, Japan, from correlation with marine glacial-interglacial cycles. Quaternary Res 39, 154-162.

Miyoshi, N., Fujiki, T., Morita, Y., 1999. Palynology of a 250-m core from Lake Biwa: a 430,000-year record of 
glacial-interglacial vegetation change in Japan. Rev Palaeobot Palyno 104, 267-283.

Moritz, M.A., Parisien, M.A., Batllori, E., Krawchuk, M.A., Van Dorn, J., Ganz, D.J., Hayhoe, K., 2012. Climate change and disruptions to global fire activity. Ecosphere 3, Article 49.

Nagahashi, Y., Sato, T., Takeshita, Y., Tawara, T., Kumon, F., 2007. Stratigraphy and chronology of widespread tephra beds intercalated in the TKN-2004 core sediment obtained from the Takano Formation, central Japan. The Quaternary Research (Daiyonki-Kenkyu) 46, 305-325.

Nagahashi, Y., Yoshikawa, S., Miyakawa, C., Uchiyama, T., Inouchi, Y., 2004. Stratigraphy and chronology of wideapread tephra layers during the past $430 \mathrm{ky}$ in the Kinki District and the Yatsugatake Mountains: Major element composition of the glass shards using EDS analysis. The Quaternary Research (Daiyonki-Kenkyu) 43, 15-35.

Nagayasu, K., Kumon, F., Takemura, K., 2014. Fossil diatom assemblages for the past 280,000 years from BIW08-B core in Lake Biwa, Japan. The Quaternary Research (Daiyonki-Kenkyu) 53, 297-309.

Nakagawa, T., Okuda, M., Yonenobu, H., Miyoshi, N., Fujiki, T., Gotanda, K., Tarasov, P.E., Morita, Y., Takemura, K., Horie, S., 2008. Regulation of the monsoon climate by two different orbital rhythms and forcing mechanisms. Geology 36, 491-494.

Ogden, J.G., 1986. An Alternative to Exotic Spore or Pollen Addition in Quantitative Microfossil Studies. Can J Earth Sci 23, 102-106.

Ogura, J., 1999. The relation between the morphology of microscopic charcoal and the original vegetation 1. Journal of Kyoto Seika University 17, 53-69.

Ohira, F., Yamamoto, M., Takemura, K., Hayashida, A., 2014. Response of vegetation in central Japan to precession during the last 147,000 years: A lignin record from Lake Biwa core BIW08-B. Quatern Int 349, 59-67.

Paillard, D., Labeyrie, L., Yiou, P., 1996. Macintosh program performs time-series analysis. Eos Transactions AGU 77, 379.

Pechony, O., Shindell, D.T., 2010. Driving forces of global wildfires over the past millennium and the forthcoming century. P Natl Acad Sci USA 107, 19167-19170.

Power, M.J., Marlon, J., Ortiz, N., Bartlein, P.J., Harrison, S.P., Mayle, F.E., Ballouche, A., Bradshaw, R.H.W., Carcaillet, C., Cordova, C., Mooney, S., Moreno, P.I., Prentice, I.C., Thonicke, K., Tinner, W., Whitlock, C., Zhang, Y., Zhao, Y., Ali, A.A., Anderson, R.S., Beer, R., Behling, H., Briles, C., Brown, K.J., Brunelle, A., Bush, M., Camill, P., Chu, G.Q., Clark, J., Colombaroli, D., Connor, S., Daniau, A.L., Daniels, M., Dodson, J., Doughty, E., Edwards, M.E., Finsinger, W., Foster, D., Frechette, J., Gaillard, M.J., Gavin, D.G., Gobet, E., Haberle, S., Hallett, D.J., Higuera, P., Hope, G., Horn, S., Inoue, J., Kaltenrieder, P., Kennedy, L., Kong, Z.C., Larsen, C., Long, C.J., Lynch, J., Lynch, E.A., McGlone, M., Meeks, S., Mensing, S., Meyer, G., Minckley, T., Mohr, J., Nelson, D.M., New, J., Newnham, R., Noti, R., Oswald, W., Pierce, J., Richard, P.J.H., Rowe, C., Goni, M.F.S., Shuman, B.N., Takahara, H., Toney, J., Turney, C., Urrego-Sanchez, D.H., Umbanhowar, C., Vandergoes, M., Vanniere, B., Vescovi, E., Walsh, M., Wang, X., Williams, N., Wilmshurst, J., Zhang, J.H., 2008. Changes in fire regimes since the Last Glacial Maximum: an assessment based on a global synthesis and analysis of charcoal data. Clim Dynam 30, 887-907.

Scholze, M., Knorr, W., Arnell, N.W., Prentice, I.C., 2006. A climate-change risk analysis for world ecosystems. P Natl Acad Sci USA 103, 13116-13120.

Scott, A.C., Bowman, D.M.J.S., Bond, W.J., Pyne, S.J., Alexander, M.E., 2014. Fire on earth: an introduction. Wiley Blackwell, Hoboken, New Jersey.

Shitaoka, Y., Fukuoka, T., Hasegawa, A., Nagatomo, T., 2013. Age determination of Sanbe Tephra (SI and SUk) as a marker for establishing paleolithic site chronology. Archaeology and Natural Science (Journal of Japan Society for scientific studies on cultural property) 64, 59-67.

Smith, V.C., Staff, R.A., Blockley, S.P.E., Ramsey, C.B., Nakagawa, T., Mark, D.E., Takemura, K., Danhara, T., Members, S.P., 2013. Identification and correlation of visible tephras in the Lake Suigetsu SG06 sedimentary archive, Japan: chronostratigraphic markers for synchronising of east Asian/west Pacific palaeoclimatic records across the last 150 ka (vol 67, pg 121, 2013). Quaternary Sci Rev 80, 206-206.

Takemura, K., Iwabe, C., Hayashida, A., Danhara, T., Kitagawa, H., Haraguchi, T., Sato, T., Ishikawa, N., 2008. Stratigraphy of marker teohras and sediments during the past 50,000 years from multiple sites in Lake Biwa, Japan. The Quaternary Research (Daiyonki-Kenkyu) 49, 147-160.

Tamai, K., 2001. Estimation model for litter moisture content ratio on forest floor. Soil-Vegetation-Atmosphere Transfer Schemes and Land-scale Hydrogical Models (Proceeding of a symposium held during the sixth IAHS Scientific Assembly at Maastrich, The Netherlands) 270, 53-57.

Tamai, K., Hattori, S., 1994. Modeling of evaporation from a forest floor in a deciduous broad-leaved forest and its application to a basin. Journal of Japanese Forest Society 76, 233-241.

Tamai, K., Goto, Y., 2006. Influence of parameters and light environment under the canopy on the fuel moisture estimation model. Journal of Japanese Forest Society 88, 150-155.

The Forest Fire Control Association, 2007. Explanation of measures against wild fire. Japan Forest Foundation, Tokyo.

Tinner, W., Conedera, M., Ammann, B., Gaggeler, H.W., Gedye, S., Jones, R., Sagesser, B., 1998. Pollen and charcoal in lake sediments compared with historically documented forest fires in southern Switzerland since AD 1920. 
Holocene 8, 31-42.

Umbanhowar, C.E., McGrath, M.J., 1998. Experimental production and analysis of microscopic charcoal from wood, leaves and grasses. Holocene 8, 341-346.

Westerling, A.L., Hidalgo, H.G., Cayan, D.R., Swetnam, T.W., 2006. Warming and earlier spring increase western US forest wildfire activity. Science 313, 940-943.

Whitlock, C., Larsen, C., 2001. Charcoal as a fire proxy, in: Smol, J.P., Birks, H.J.B., Last, W.M. (Eds.), Terrestrial, Algal, and Siliceous Indicators. Kluwer Academic Publisher, Dordrecht, pp. 75-97.

Yoshikawa, S., Inouchi, Y., 1993. Middle Pleistocene to Holocene explosive volcanism revealed by shes of the Takashima-oki Core samples from Lake Biwa, central Japan. Earth Science (Chikyu Kagaku) 47, 97-109.

Xiao, J.L., An, Z.S., Liu, T.S., Inouchi, Y., Kumai, H., Yoshikawa, S., Kondo, Y., 1999. East Asian monsoon variation during the last 130,000 Years: evidence from the Loess Plateau of central China and Lake Biwa of Japan. Quaternary Sci Rev 18, 147-157.

Xiao, J.L., Inouchi, Y., Kumai, H., Yoshikawa, S., Kondo, Y., Liu, T.S., An, Z.S., 1997a. Biogenic silica record in Lake Biwa of central Japan over the past 145,000 years. Quaternary Res 47, 277-283.

Xiao, J.L., Inouchi, Y., Kumai, H., Yoshikawa, S., Kondo, Y., Liu, T.S., An, Z.S., 1997b. Eolian quartz flux to Lake Biwa, central Japan, over the past 145,000 years. Quaternary Res 48, 48-57. 


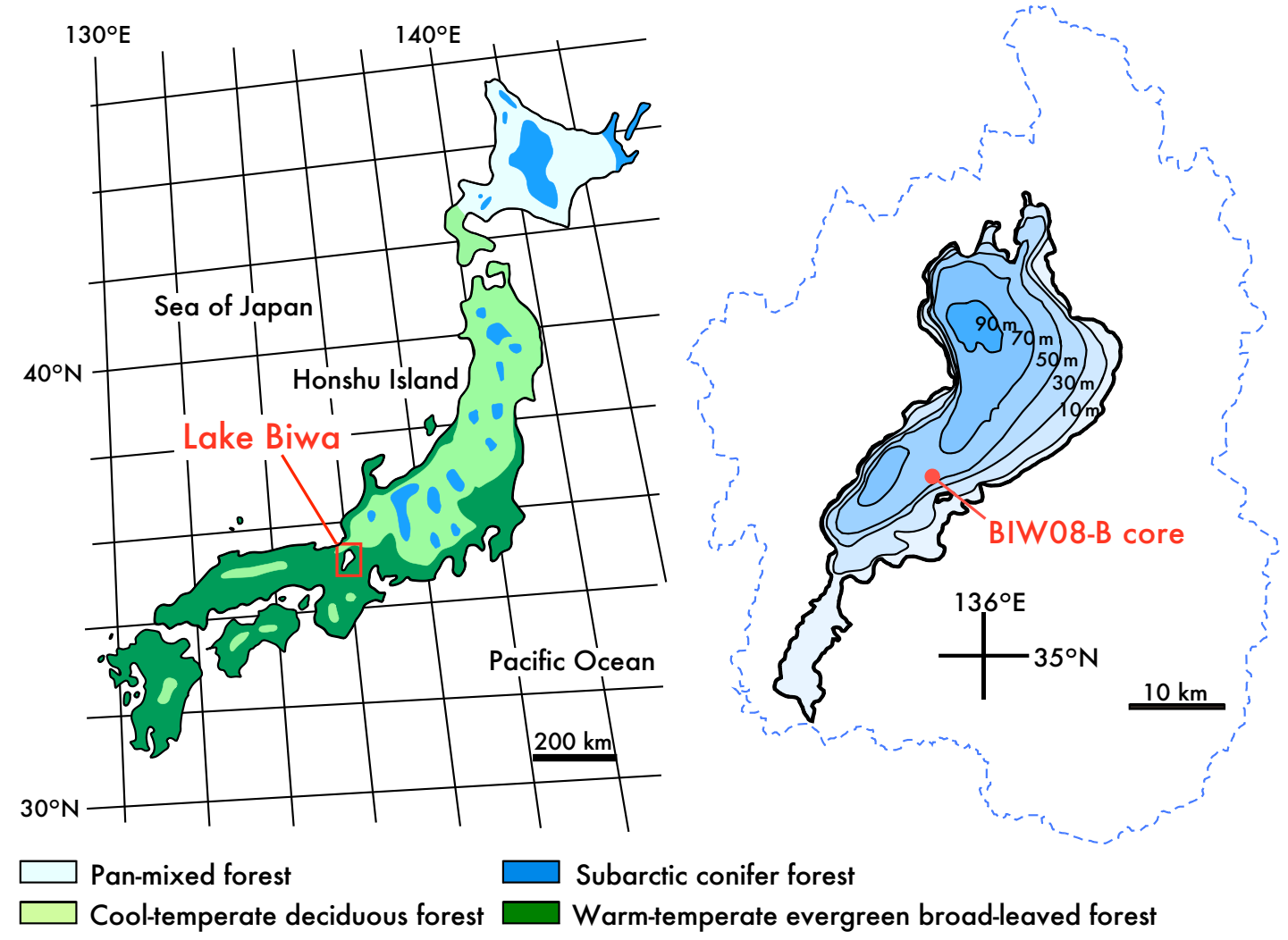

Fig. 1. Map of Japan showing modern vegetation type, compiled by Igarashi and Oba (2006). Map of Lake Biwa showing the coring site of BIW08-B (right). The dashed blue line indicates the lake's watershed area.

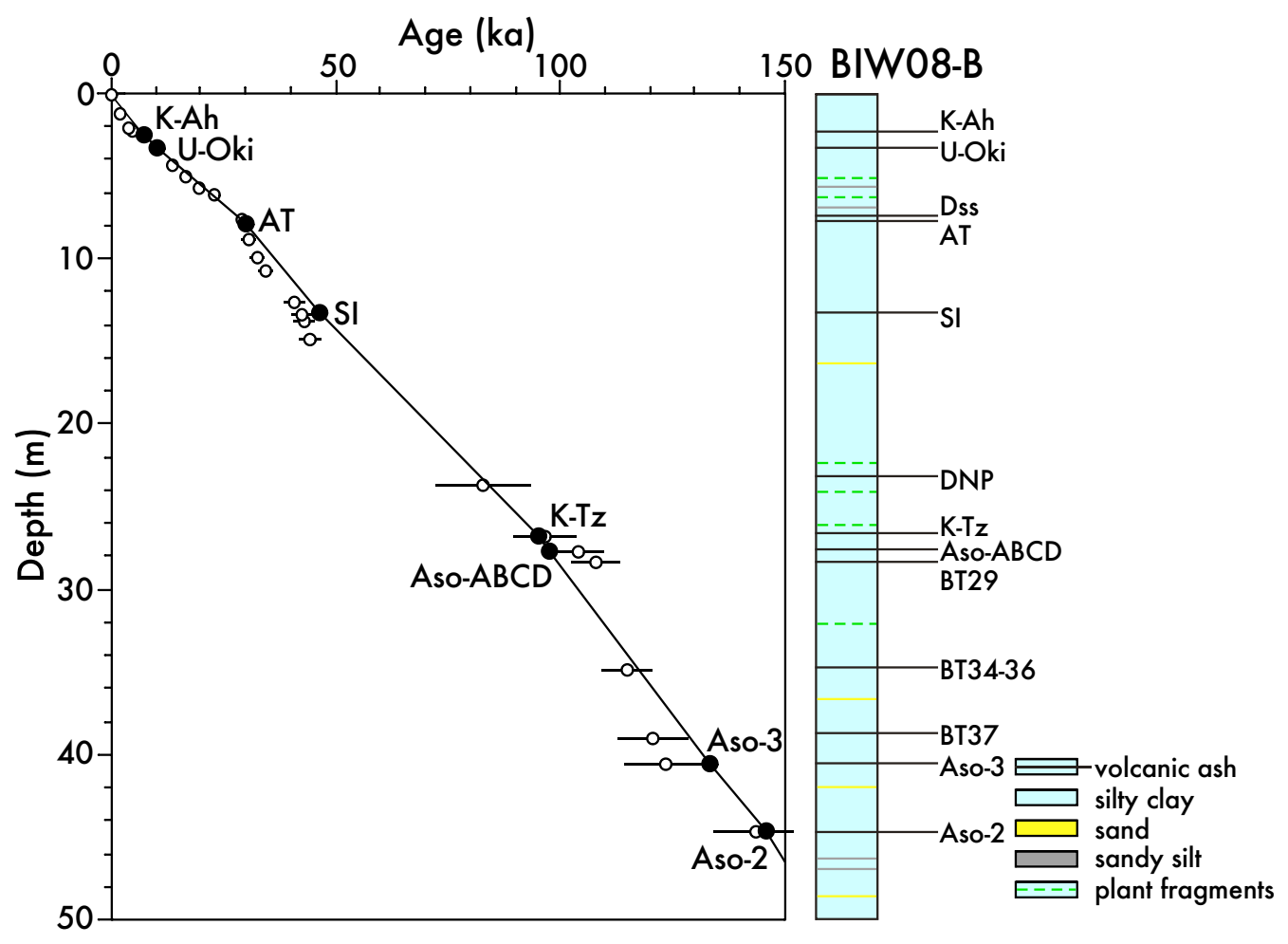

Fig. 2. Lithology of the BIW08-B core after Takemura et al. (2010), and the age-model of the core after Nagayasu et al. (2014). White circles with bars indicate radiometric age or ages of anhysteretic remanent magnetization events $(2 \sigma)$ compiled by Ohira et al. (2014). 

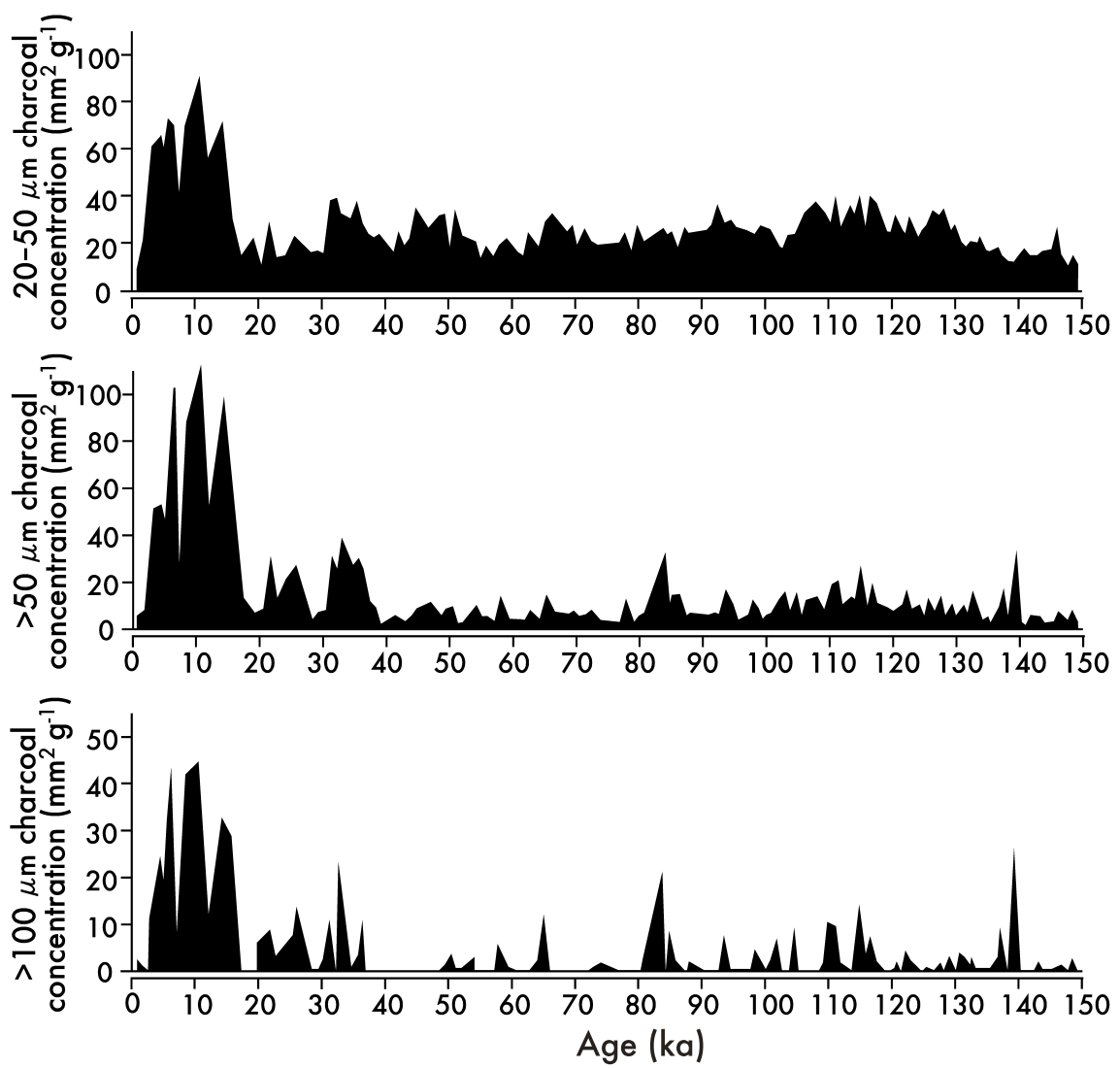

Fig. 3 Concentrations of $20-50 \mu \mathrm{m},>50 \mu \mathrm{m}$, and $>100 \mu \mathrm{m}$ charcoal particles in Lake Biwa sediments in the last $150 \mathrm{ky}$.

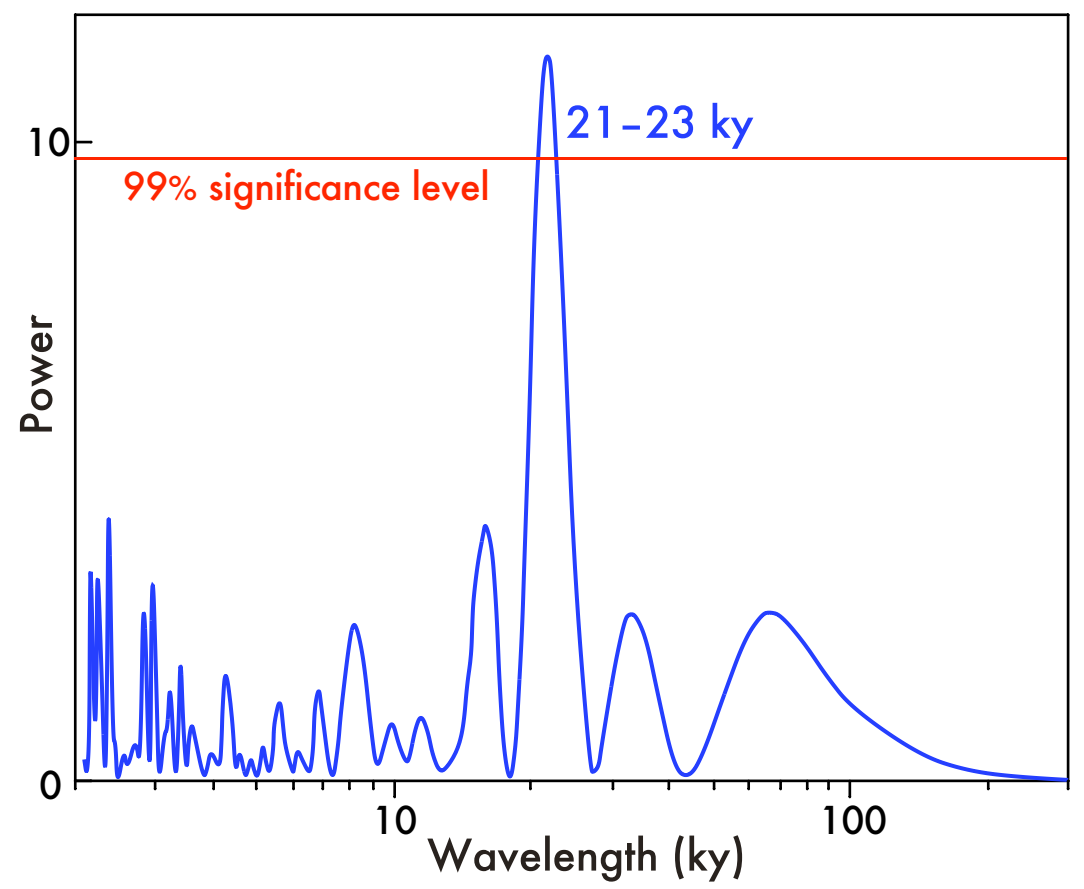

Fig. 5. Spectral analysis of 20-50 $\mu \mathrm{m}$ charcoal concentration $\left(\mathrm{mm}^{2} \mathrm{~g}^{-1}\right)$ between 130 and $40 \mathrm{ka}$ using Past software (Hammer et al, 2001; available at http://folk.uio.nøohammer/past/).

The Lomb periodogram algorithm for unevenly sampled data was applied. The data were automatically detrended prior to analysis. 


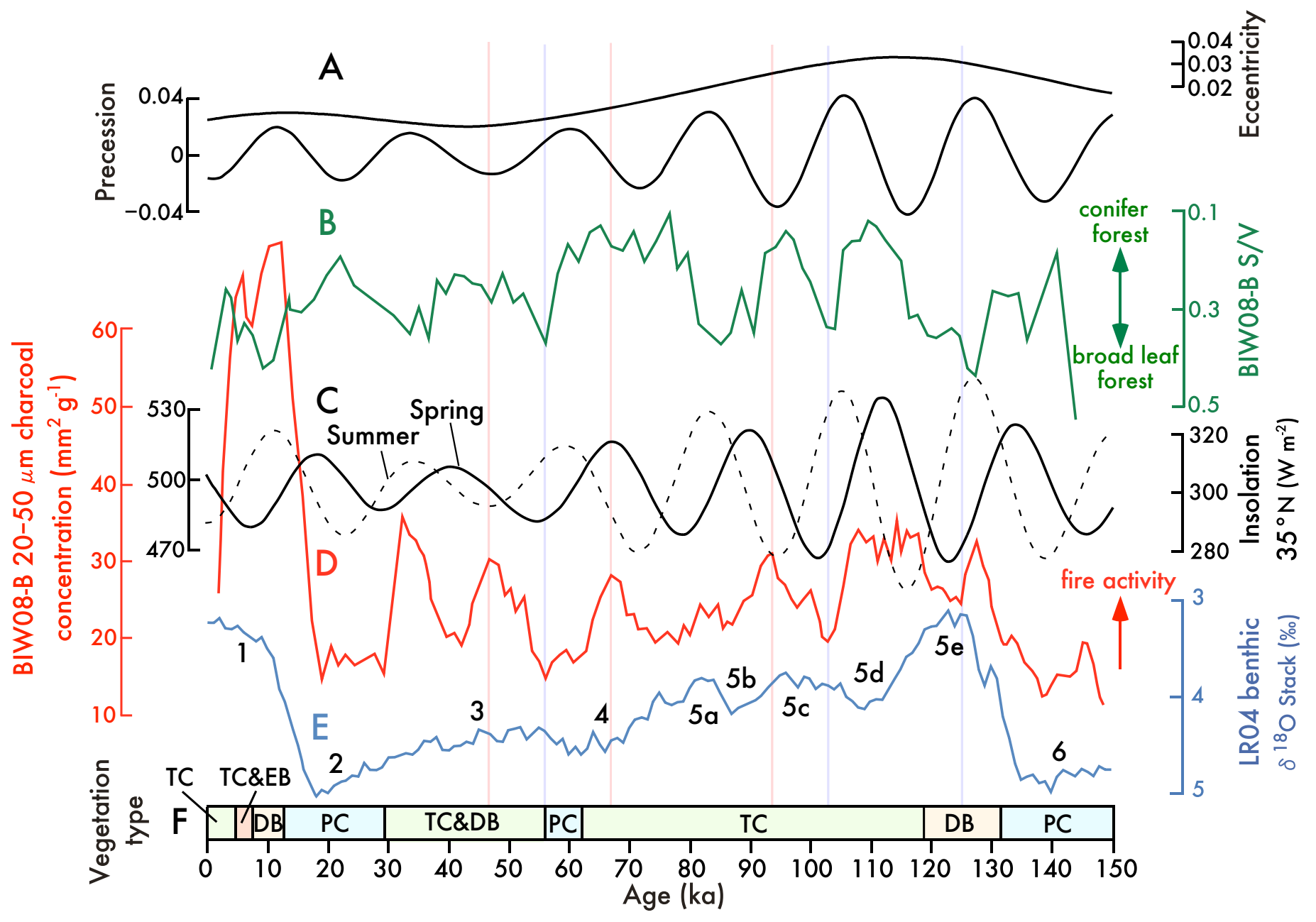

Fig. 4 Variation in fire activity in central Japan (D), compared to the eccentricity and precession index (A), spring and summer insolation $(C)$, ice volume implying global climate $(E)$, and vegetation change (B and F). A: the eccentricity and precession index (Lasker et al., 2004) calculated using Analysis Series 2.0 for Macintosh (Paillard et al., 1996). B: Ratio of syringyl to vanillyl phenols (S/V ratio) in the BIW08-B core (Ohira et al., 2014) represents an index of angiosperms versus gymnosperms, reflecting an index of deciduous broad-leaved trees versus pinaceous and temperate conifer trees. C: Spring (March 1) and summer insolation (June 21) at $35^{\circ} \mathrm{N}$ (Berger, 1978) calculated using Analysis Series 2.0 for Macintosh (Paillard et al., 1996). D: Three-sample running average of 20-50 $\mu \mathrm{m}$ charcoal particle concentrations from the BIW08-B core, representing fire activity in the regional area. E: LR04 marine isotope stack (Lisiecki and Raymo, 2005). F: Vegetation type inferred from palynological data of sediment cores from Lake Biwa (Hayashi et al., 2010a, b; 2017); PC: Pinaceous conifer trees, DB: Deciduous broad-leaved trees, TC: Temperate conifer trees, EB: Evergreen broad-leaved trees. 

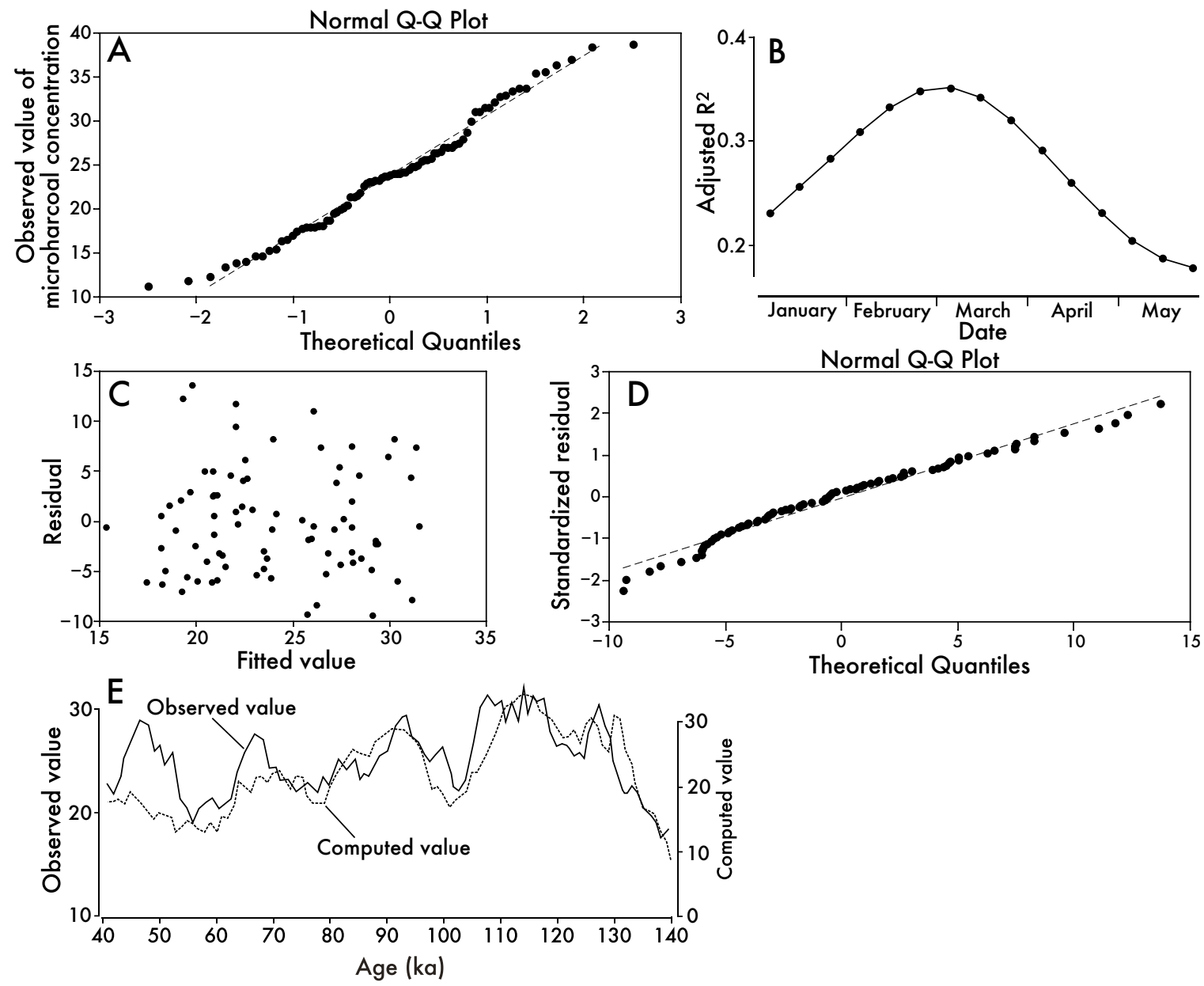

Fig. 6 (a) Normal Q-Q plot of the observed value of 20-50 $\mu \mathrm{m}$ charcoal concentration (three-sample running average) between 130 and $40 \mathrm{ka}$, (b) Adjusted $\mathrm{R}^{2}$ values obtained from multiple regression analysis using marine isotope stack and insolation at each date (every $\sim 10$ days, i.e., January $1,11,21$, February $1,11, \ldots$ ) from January to May and 20-50 $\mu \mathrm{m}$ charcoal concentrations. (c) Distribution of residuals in a multiple regression analysis using a marine isotope stack and the insolation on March 1 and the 20-50 $\mu \mathrm{m}$ charcoal concentrations; the multiple $r$ is 0.61 and the adjusted $R^{2}$ is 0.35 . (d) Normal Q-Q plot of the standardized residuals in the multiple regression analysis. (e) Comparison between charcoal concentrations computed using multiple regression analysis (computed value) and original charcoal concentration in the BIW08-B core (observed value). The regression equation of computed charcoal concentration is

$\mathrm{CC}=-9.56 * \mathrm{OI}+0.204 * \mathrm{SI}+1.33$, where $\mathrm{CC}$ is the charcoal concentration, $\mathrm{OI}$ is the oxygen isotope ratio in the LR04 marine isotope stack, and SI is early-spring insolation (March 1) at $35^{\circ} \mathrm{N}$. 


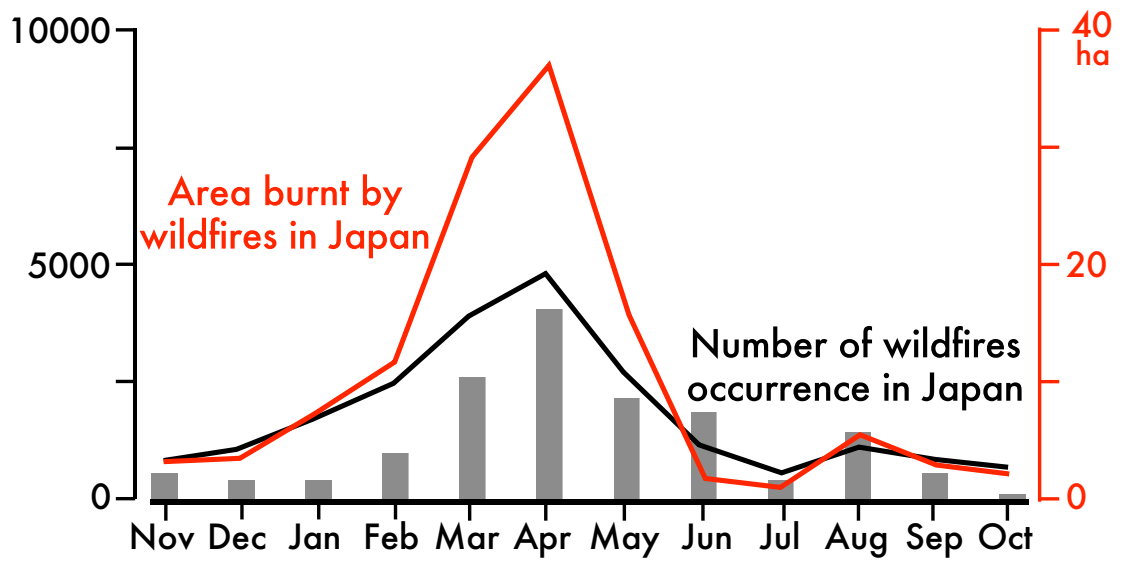

$10[$ Number of wildfires occurrence in watershed area of Lake Biwa
Fig. 7 Sum of the number of wildfire occurrence (black line), sum of burnt area of wildfires (red line) in each month in Japan between A.D. 2001 and 2011, and sum of the number of wildfire occurrences in each month in Shiga Prefecture almost corresponding to watershed area of Lake Biwa (see Fig. 1) between A.D. 1999 and 2003 (gray bars). Data in Japan are from the Japanese Fire and Disaster Management Agency (2002-2012), and data in Shiga Prefecture are from the Japanese Fire and Disaster Management Agency (2005).

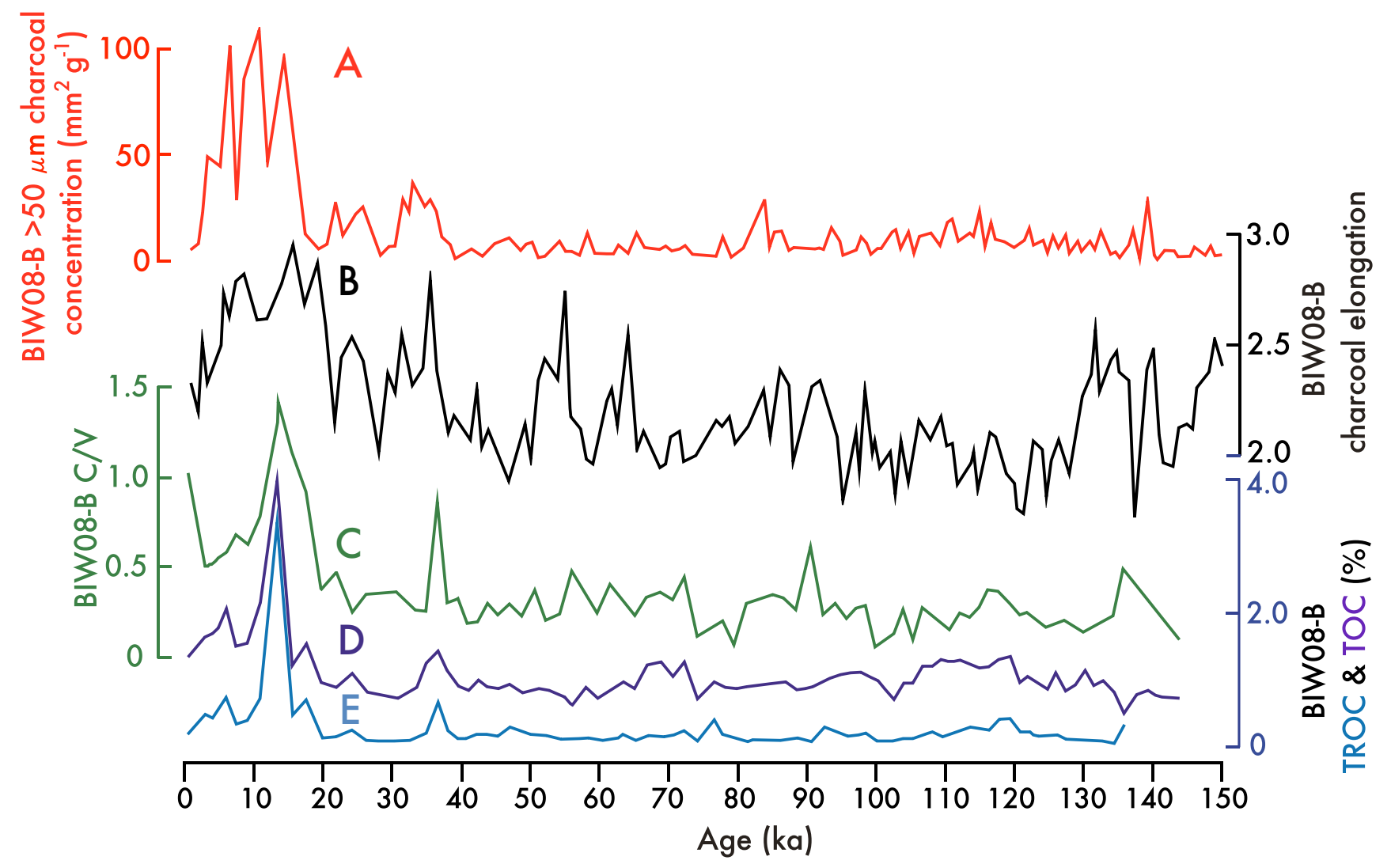

Fig. 8 Variation in fire activity and vegetation in the lakeside area of Lake Biwa. A: $>50 \mu \mathrm{m}$ charcoal concentrations in Lake Biwa. B: Elongation of 20-50 $\mu \mathrm{m}$ charcoal. C: Ratio of cinnamyl to vanillyl phenols ( $\mathrm{C} / \mathrm{V}$ ratio) in the BIW08-B core represents an index of contribution from herbaceous plants (Ohira et al., 2014). D: Total organic carbon content (TOC). E: Terrestrial organic carbon content (TROC) after Ohira et al. (2014).

Supplementary Table 1 Results of multiple regression analysis between marine isotope stack and insolation at March 1 and 20-50 $\mu \mathrm{m}$ charcoal concentrations.

Supplementary Table 2 Concentrations of 20-50 $\mu \mathrm{m},>50 \mu \mathrm{m}$, and $>100 \mu \mathrm{m}$ charcoal particles with ages in the BIW08-B core in the last $150 \mathrm{ky}$.

Supplementary data related to this article can be found at https://doi.org/10.1016/j.quascirev.2017.11.007. 